\title{
RESEARCH
}

Open Access

\section{Human multipotent adult progenitor cell- conditioned medium improves wound healing through modulating inflammation and angiogenesis in mice}

Parinaz Ahangar ${ }^{1,2}$, Stuart J. Mills ${ }^{1,2}$, Louise E. Smith ${ }^{1,2}$, Xanthe L. Strudwick ${ }^{1}$, Anthony E. Ting ${ }^{3}$, Bart Vaes ${ }^{4}$ and Allison J. Cowin ${ }^{1,2^{*}}$ (D)

\begin{abstract}
Background: Stem cell therapies have been widely investigated for their healing effects. However, the translation of these therapies has been hampered by the requirement to deliver live allogeneic or autologous cells directly to the wound in a clinical setting. Multipotent adult progenitor cells (MAPC ${ }^{\circledR}$ cells) are a subpopulation of bone marrow-derived adherent stem cells that secrete a wide range of factors known to accelerate the wound healing process. The aim of this study was to determine the impact of MAPC cells secretome on healing outcomes without the presence of MAPC cells.

Methods: The effect of MAPC-conditioned medium (MAPC-CM) on the capacity of keratinocytes, fibroblasts and endothelial cells to migrate and proliferate was determined in vitro using scratch wound closure and WST1 assay, respectively. The effect of MAPC-CM on collagen deposition and angiogenesis was also assessed using in vitro methods. Additionally, two excisional wounds were created on the dorsal surface of mice ( $n=8 /$ group) and $100 \mu \mathrm{L}$ of 20X MAPC-CM were intradermally injected to the wound margins. Wound tissues were collected at 3, 7 and 14 days post-wounding and stained with H\&E for microscopic analysis. Immunohistochemistry was performed to investigate inflammation, angiogenesis and collagen deposition in the wounds.

Results: Skin fibroblasts, keratinocytes and endothelial cells treated with MAPC-CM all showed improved rates of scratch closure and increased cellular proliferation. Moreover, fibroblasts treated with MAPC-CM deposited more collagens I and III and endothelial cells treated with MAPC-CM showed increased capillary tube formation. Murine excisional wounds intradermally injected with MAPC-CM showed a significant reduction in the wound area and an increase in the rate of reepithelialisation. The results also showed that inflammatory cell infiltration was decreased while an increase in angiogenesis, as well as collagens I and III expressions, was observed.
\end{abstract}

(Continued on next page)

\footnotetext{
* Correspondence: allison.cowin@unisa.edu.au

'Future Industries Institute, University of South Australia, Adelaide, SA 5000, Australia

${ }^{2}$ Cell Therapy Manufacturing Cooperative Research Centre, Adelaide, SA 5000, Australia

Full list of author information is available at the end of the article
}

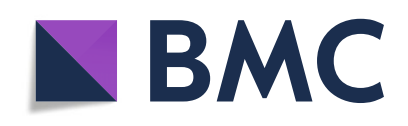

(- The Author(s). 2020 Open Access This article is licensed under a Creative Commons Attribution 4.0 International License, which permits use, sharing, adaptation, distribution and reproduction in any medium or format, as long as you give appropriate credit to the original author(s) and the source, provide a link to the Creative Commons licence, and indicate if changes were made. The images or other third party material in this article are included in the article's Creative Commons licence, unless indicated otherwise in a credit line to the material. If material is not included in the article's Creative Commons licence and your intended use is not permitted by statutory regulation or exceeds the permitted use, you will need to obtain permission directly from the copyright holder. To view a copy of this licence, visit http://creativecommons.org/licenses/by/4.0/. The Creative Commons Public Domain Dedication waiver (http://creativecommons.org/publicdomain/zero/1.0/) applies to the data made available in this article, unless otherwise stated in a credit line to the data. 
(Continued from previous page)

Conclusion: These findings suggest that factors produced by MAPC cells can have an important effect on cutaneous wound healing by affecting skin cell proliferation and migration, balancing inflammation and improving the formation of extracellular matrix and angiogenesis. Development of stem cell-free therapy for the treatment of wounds may be a more clinically translatable approach for improving healing outcomes.

Keywords: Wound healing, Multipotent adult progenitor cells, Secretome, Conditioned medium, Inflammation, Angiogenesis

\section{Introduction}

Wound healing is a well-coordinated process in which various cell types receive external signals causing them to proliferate, migrate, differentiate and synthesise proteins to restore the multilayered tissue of skin [1]. During wound healing, fibroblasts from the surrounding dermal layer proliferate and migrate into the wound site. Fibroblasts in the wound area deposit extracellular matrix (ECM) into the wound bed, which results in the formation of new granulation tissue [2]. Simultaneously, endothelial cells migrate into the wound bed and create tube-like structures, which form the foundation of new blood vessels. Finally, the skin barrier is restored during the re-epithelialisation process where keratinocytes proliferate and migrate across the wound bed to form the neo-epidermis [3]. Any dysfunction in the cutaneous wound healing process such as prolonged inflammation, delayed proliferation and/or excessive collagen deposition results in the formation of chronic wounds and additional scarring in human adults [4].

Therapeutic potential of stem cells has been investigated for the repair and regeneration of damaged tissues and both preclinical and clinical trials have shown great promise for the use of stem cells in wound healing improvement $[5,6]$. However, the development of stem cell therapies for the treatment of wounds has been hampered by the requirement to deliver large numbers of live, functional cells to patients [7].

Stem cell differentiation and direct incorporation into regenerating tissues were speculated to be the primary mechanisms of mesenchymal stem cell (MSC) actions [8]. However, several cases have demonstrated that frequency of stem cell engraftment and the number of newly generated cells, either by differentiation or by cell fusion, appears to be too low to explain significant effects achieved by stem cells [9]. Proteomic analysis of stem cell conditioned media indicates that stem cells secrete a wide range of biomolecules which can contribute to tissue regeneration including mRNAs, active lipids, growth factors and cytokines [10]. Therefore, the paracrine signalling of stem cells has been suggested as the main mechanism for the actions of stem cells [9]. Evidence from several in vitro and in vivo studies suggest that beneficial effects of stem cell therapies on wound healing are achieved via their paracrine effects on skin cells. This increases the rate of proliferation and migration and functionality in resident immune cells, keratinocytes, fibroblasts and endothelial cells [11].

Multipotent adult progenitor cells (MAPC cells) are a sub-set of adherent stem cells that have outstanding plasticity and self-renew ability [12]. These cells initially were derived from adult bone marrow [12] but have also been isolated from brain and muscle tissues [13]. In comparison with MSCs, MAPC cells have been considered as a more biologically primitive population with greater differentiation and proliferation potential [14]. Previously published studies have confirmed MAPC cells as a distinct cell-type separate from MSCs with different phenotype, function, differentiation and expansion capacity, required culture conditions and transcriptional profile [12, 15-17]. Furthermore, MAPC cells and MSCs possess distinct secretomes based on their surrounding environments [18]. Analysis of these secretomes has demonstrated that MAPC cells respond to various stimuli by secreting a wide range of growth factors and cytokines which affect processes such as angiogenesis, immune function, fibrosis, and apoptosis, all key processes during wound healing [19].

This paper aimed to investigate whether human MAPC-conditioned medium (MAPC-CM) could accelerate cutaneous wound healing in vitro and in vivo. First, proteins secreted by MAPC cells were identified using a bead array assay. Second, the effect of MAPC-CM on proliferation, migration and functionality of cutaneous cells including keratinocytes, fibroblasts and endothelial cells was determined using in vitro methods. Finally, the effect of MAPC-CM on excisional wound healing was investigated using a murine wound healing model. In order to evaluate this effect, macroscopic and microscopic assessments were employed. Moreover, the impact of this treatment on inflammation, angiogenesis and collagen deposition was determined in the healing wounds.

\section{Materials and methods}

\section{Cell culture}

Human MAPC cells were provided by ReGenesys BVBA (Heverlee, Belgium). MAPC cells were isolated from a 
single bone marrow aspirate, obtained with consent from a healthy donor and subsequently expanded on a Quantum cell expansion system (Terumo BCT, Lakewood, USA) according to previously described methods [16]. Cells were further expanded on fibronectin-coated plastic tissue culture flasks. Cell cultures were maintained under low oxygen tension in a humidified atmosphere of $5 \% \mathrm{CO}_{2}$. Cells were cultured to sub-confluence in MAPC culture media (lowglucose DMEM (Thermo Fisher Scientific, VIC, Australia) supplemented with foetal bovine serum (FBS, Atlas Biologicals, Fort Collins, USA), ITS liquid media supplement (Sigma-Aldrich, NSW, Australia), MCDB (Sigma-Aldrich, NSW, Australia), platelet-derived growth factor (R\&D Systems, Minneapolis, USA), epidermal growth factor (R\&D Systems), dexamethasone (Sigma-Aldrich, NSW, Australia), penicillin/streptomycin (Invitrogen, CA, USA), 2-PhosphoL-ascorbic acid (Sigma-Aldrich, NSW, Australia) and linoleic acid-albumin (Invitrogen, CA, USA)). Cells were passaged every 3-4 days and harvested using trypsin/EDTA (Invitrogen, CA, USA). Transcriptome analysis confirmed that MAPC cells are distinct cell population from MSCs at the point of use (Supplementary Information and Fig. S1).

Human foreskin fibroblasts (HFFs, CellBank Australia, NSW, Australia) and human immortalised keratinocytes (HaCaTs, ATCC, Virginia, USA) were cultured in lowglucose DMEM medium (Thermo Fisher Scientific, VIC, Australia) with $2 \mathrm{mM}$ L-glutamine, 10\% FBS (Thermo Fisher Scientific, VIC, Australia) and $100 \mathrm{U} / \mathrm{mL}$ penicillin/streptomycin (Lonza, Basel, Switzerland). Human dermal microvascular endothelial cells (HDMECs, PromoCell, Heidelberg, Germany) were grown in endothelial cell growth medium MV2 (PromoCell, Heidelberg, Germany) with $2 \mathrm{mM} \mathrm{L-glutamine,} \mathrm{10 \%} \mathrm{FBS} \mathrm{and} 100 \mathrm{U} /$ $\mathrm{mL}$ penicillin/streptomycin (Lonza, Basel, Switzerland). These three cell types were incubated at $5 \% \mathrm{CO}_{2}, 37^{\circ} \mathrm{C}$ and $95 \%$ humidity.

\section{MAPC-conditioned medium collection}

To harvest MAPC-CM, $2 \times 10^{3}$ cells per $\mathrm{cm}^{2}$ were seeded into T75 flasks. Upon reaching 70\% confluency, MAPC medium was removed, flasks were washed twice with phosphate-buffered saline (PBS) and $10 \mathrm{~mL}$ FBSfree DMEM medium was added to the flasks. Following $24 \mathrm{~h}$ incubation under hypoxia conditions, the conditioned medium was collected from each flask. To obtain consistent small batches of CM, the conditioned media of MAPC cells in 20 flasks were combined, centrifuged at $350 \mathrm{~g}$ for $10 \mathrm{~min}$ and sterilised using $0.22 \mu \mathrm{m}$ filters. For in vivo applications, the conditioned medium was concentrated $20 \times$ using GE Vivaspin ${ }^{\mathrm{TM}}$ protein concentrator spin columns (Bio-strategy, VIC, Australia). Aliquots were kept in $-80{ }^{\circ} \mathrm{C}$ freezer until use. In all experiments, fresh FBS-supplemented DMEM with 10\% FBS was used as the positive control while fresh FBS-free DMEM medium was used as the negative control.

\section{Bead array assay}

A bead-based immunoassay was employed to detect and quantify the concentration of soluble proteins in MAPC$\mathrm{CM}$ including growth factors, adhesion molecules and inflammatory cytokines. The experiment was performed according to the manufacturer's protocols (BioLegend's LEGENDplex $^{\mathrm{Tm}}$, CA, USA). Briefly, human MAPC cells were cultured for at least two passages under normal culture conditions. Prior to the collection of conditioned medium, MAPC cells (75-85\% confluent) were cultured in FBS-free DMEM for $24 \mathrm{~h}$ in the absence of any exogenous stimuli. Then, the collected conditioned medium was concentrated $20 \times$ using GE Vivaspin ${ }^{\mathrm{TM}}$ protein concentrator spin columns. Concentrated conditioned medium and standards were incubated with antibody-conjugated capture beads for each protein for $2 \mathrm{~h}$ with shaking. Following binding of the capture beads with their target proteins, biotinylated detection antibodies were added to the wells and incubated for an hour with shaking. Streptavidin phycoerythrin (SA-PE) was added to the wells and incubated for $30 \mathrm{~min}$. After washing with SA-PE, the wells were loaded with wash buffer and read using a BD LSRFortessa ${ }^{\mathrm{TM}}$ flow cytometer (BD Bioscience, CA, USA).

\section{Cell proliferation assay}

The effect of MAPC-CM on the proliferation of HFFs, $\mathrm{HaCaTs}$ and HDMECs was analysed using the WST-1 (2(4-iodophenyl)-3-(4-nitrophenyl)-5-(2,4-disulfophenyl)-2Htetrazolium monosodium salt) proliferation assay according to the manufacturer's protocols (Roche Applied Science, Bavaria, Germany). In brief, cells were plated onto 96-well plates at the density of $5 \times 10^{3}$ cells/well in their own recommended culture conditions. When they reached 25-35\% confluence, cells were washed with PBS to remove media and the media were replaced with either FBS-free DMEM (negative control), DMEM with 10\% FBS (positive control) or MAPC-CM. Following $24 \mathrm{~h}$ incubation, WST-1 (10\%) was added to each plate and the absorbance was measured at $460 \mathrm{~nm}$ using a microplate reader (Tecan Group, Mannedorf, Switzerland).

\section{Scratch wound closure assay}

Migration of dermal fibroblasts, keratinocytes and endothelial cells in MAPC-CM was assessed using a scratch wound closure assay. To conduct this assay, cells were seeded onto 96-well plates at the density of $3 \times 10^{4}$ cells/ well in their own recommended media and maintained until reaching 80-90\% confluency. Cell monolayers were scratched using a wound maker ${ }^{\mathrm{Tm}}$ (Essen bioscience, MI, USA). After scratching, wells were washed twice using 
PBS and their culture media was replaced with either FBS-free DMEM (negative control), DMEM with $10 \%$ FBS (positive control) or MAPC-CM. Plates were then placed in the IncuCyte (Essen bioscience, MI, USA) to record the scratch wound closure by taking images immediately after scratching and every $3 \mathrm{~h}$ until complete wound closure. For the study on the MAPC-CM, the remaining scratch area of each well was calculated and presented as the extent of wound closure.

\section{Collagen I and III staining of fibroblasts}

Collagens I and III were determined using a 96-well immunohistochemistry assay [20]. HFFs were seeded in DMEM with $10 \% \mathrm{FBS}$ at $5 \times 10^{4}$ cells/well into 96-well plates. The medium was replaced with test reagents after $24 \mathrm{~h}$. Plates were left in the incubator for $60 \mathrm{~h}$ to allow collagens to be deposited. Cells were washed with PBS, fixed and permeabilised in ice-cold methanol $\left(-20^{\circ} \mathrm{C}\right)$. Cells were then treated with Tween 20 (0.5\%) in PBS for $10 \mathrm{~min}$ before incubating in $3 \%$ normal goat serum (NGS, Thermo Fisher Scientific, VIC, Australia) for $30 \mathrm{~min}$ and finally incubating with rabbit anti-human collagen type I antibody $(5 \mu \mathrm{g} / \mathrm{mL}$, Rockland Immunochemicals, USA) and rabbit anti-human collagen type III Antibody $(5 \mu \mathrm{g} / \mathrm{mL}$, Rockland Immunochemicals, USA) at room temperature for $2 \mathrm{~h}$. Secondary antibody goat anti-rabbit IgG Alexa Fluor $488(5 \mu \mathrm{g} / \mathrm{mL}$, Invitrogen, CA, USA) was added to cells for an hour. Nuclear fluorescent dye (DAPI, (4', 6-diamidino-2phenylindole)) was added prior to imaging. The plate was then imaged using an Olympus IX83 fluorescence microscope and the fluorescence intensity of the wells was measured in order to determine the expression of collagens I and III.

\section{Matrigel tube formation assay}

An in vitro tube formation assay was employed in order to examine the possible effect of MAPC-CM on blood vessel formation. This assay investigates the ability of human endothelial cells to form tube-like networks and tube sprouts after incubation in MAPC-CM. Ten microlitres growth factor reduced Matrigel (Corning Life Science, New York, USA) was added to each well of Ibidi $\mathrm{u}$-slide angiogenesis 15-well plates (ibidi $\mathrm{GmbH}$, Bavaria, Germany), which then was incubated at $37^{\circ} \mathrm{C}$ for 30 min. HDMECs $\left(1.5 \times 10^{4}\right)$ suspended in $50 \mu \mathrm{L}$ of either FBS-free DMEM (negative control), DMEM with $10 \%$ FBS (positive control) or MAPC-CM were seeded in each well and images were taken every $3 \mathrm{~h}$ using an Olympus IX81 microscope (Olympus, Tokyo, Japan). The number of tubes in each well was counted every $3 \mathrm{~h}$ until all tubes were degraded.

\section{Murine model of excisional wound healing}

Female BALB/c mice 10-12 weeks old were used for the study. Two $6 \mathrm{~mm}^{2}$ full-thickness dorsal excisional wounds were created $5 \mathrm{~mm}$ either side of the midline and $10 \mathrm{~mm}$ from the base of the skull. One hundred microlitres of $20 \times$ concentrated conditioned medium was injected at four sites into the margins of each wound. One hundred microlitres FBS-free DMEM was injected at four sites into the margins of wounds in the control group ( $n=8$ /group). Digital photographs of the wounds were taken for macroscopic analysis of wound healing and wounds were harvested at days 3, 7 and 14 post-injury for histological and immunohistochemical analysis.

\section{Histological and immunohistochemistry analyses of wound tissues}

Histological sections $(4 \mu \mathrm{m})$ from paraffin-embedded fixed tissues were stained with haematoxylin and eosin $(\mathrm{H} \& \mathrm{E})$ for microscopic analysis of wound healing. The sections were also stained with Masson's trichrome stain for total collagen analysis. Moreover, sections were subjected to immunohistochemistry, similar to previous studies [21], following antigen retrieval. Tissue sections were blocked in 3\% blocking NGS for $30 \mathrm{~min}$ at room temperature, incubated with rabbit anti-human collagen type I $(5 \mu \mathrm{g} / \mathrm{mL}$, Rockland Immunochemicals, Pennsylvania, USA), rabbit anti-human collagen type III $(5 \mu \mathrm{g} / \mathrm{mL}$, Rockland Immunochemicals, Pennsylvania, USA), rat neutrophil marker (NIMP-R14, $0.5 \mu \mathrm{g} / \mathrm{mL}$, Santa Cruz Biotechnology, Texas, USA) and rabbit anti-CD31 $(0.2 \mu \mathrm{g} / \mathrm{mL}$, Abcam, Cambridge, UK), F4/80 $(5 \mu \mathrm{g} / \mathrm{mL}$, Bio-Rad, NSW, Australia), YM-1 $(0.37 \mu \mathrm{g} / \mathrm{mL}$, StemCell technologies, Vancouver, Canada) antibodies overnight at $4{ }^{\circ} \mathrm{C}$. Subsequently, tissue sections were stained with secondary goat anti-rabbit IgG, Alexa Fluor 488, goat anti-rabbit IgG, Alexa Fluor 568 or goat anti-rat IgG Alexa Fluor $488(5 \mu \mathrm{g} / \mathrm{mL}$, Invitrogen, CA, USA). To visualise nuclei and overall tissue architecture, sections were stained for $5 \mathrm{~min}$ in 4',6-diamidino-2-phenylindole (DAPI, 1:5000 of $1 \mathrm{mg} / \mathrm{mL}$ stock). Sections were imaged with Olympus IX81 microscope (Olympus, Tokyo, Japan).

\section{Statistical analysis}

The results are presented as mean \pm SEM. Data analysis was performed using GraphPad Prism (Graphpad, CA, USA). One-way and two-way analysis of variance (ANOVA) tests were used for multiple comparisons followed by Tukey and Bonferroni post-tests. Data are representative of the means of at least three independent experiments and values. A value of $p<0.05$ was set for the significance value. 


\section{Results}

Secretome analysis of MAPC cells and identification of proteins correlated to wound healing

In order to identify proteins secreted into the conditioned media by MAPC cells, bead array assays were employed. This assay was conducted to quantify a number of proteins associated with wound healing including growth factors, inflammatory cytokines and adhesion molecules. The concentration of secreted proteins found in conditioned media of MAPC cells is shown in Table 1 along with their role in wound healing. Note that no protein was detected in FBS-free DMEM.

\section{MAPC-CM increases the proliferation and migration of fibroblasts, keratinocytes and endothelial cells}

To measure the effect of MAPC-CM on skin cells proliferation, a WST-1 assay was used. As shown in Fig. 1, the proliferation of $\mathrm{HaCaTs}$ was significantly increased by $17.4 \%$ following $24 \mathrm{~h}$ of treatment with MAPC-CM in comparison to the FBS-free DMEM (negative control) (Fig. 1a, d). Proliferation of MAPC-CM-treated HFFs was also increased by $8.8 \%$ (Fig. 1b, e). HDMECs similarly showed elevated proliferative ability with an increase of $29.3 \%$ over the negative control (Fig. 1c, f).

In order to determine the effect of MAPC-CM on the migration ability of skin cells, a scratch wound closure assay was used. Migration of $\mathrm{HaCaTs}$ into the scratch area was significantly enhanced from the first time point $(3 \mathrm{~h})$ after scratch, while cells in FBS-free DMEM (negative control) had not started to migrate (Fig. 2a, d). Migration of HaCaTs into the scratched area was significantly increased at each time point compared to the negative control. This increase was even significantly higher than the DMEM $+10 \%$ FBS (positive control) at each time point (Fig. 2a, d). Migration ability of HFFs was also significantly enhanced following $9 \mathrm{~h}$ of treatment with MAPC-CM compared to negative control medium (Fig. 2b, e). Similarly, migration of HDMECs was enhanced in the presence of MAPC-CM, which was statistically significant $15 \mathrm{~h}$ after scratching (Fig. 2c, f).

MAPC-CM encourages tube formation of endothelial cells and increases the halftime life of formed tubes

An in vitro tube formation assay was conducted in order to examine the possible effects of MAPC-CM on blood vessel formation. Tube formation of HDMECs was quantified by counting the average number of tube-like structures (Fig. 3a). HDMECs formed the maximum number of blood vessel-like structures in all three groups after $3 \mathrm{~h}$ after which tubes began to degrade. As indicated in Fig. 3b, the average number of tube-like structures in each time point was significantly higher in HDMECs incubated with MAPC-CM compared with those incubated with FBS-free DMEM (negative control).

Degradation of tube-like structures began after $3 \mathrm{~h}$, with all structures in FBS-free DMEM (negative control) and DMEM with 10\% FBS (positive control) being degraded after 30 and $72 \mathrm{~h}$, respectively. The overall number of tubes remained significantly elevated at each time point in MAPC-CM wells, with a prolonged half-life of tubes observed up to $96 \mathrm{~h}$ (Fig. 3b). These results indicate the positive effect of MAPC-CM impact not only on vessel formation but also on vessel stabilisation.

Table 1 MAPC cell protein secretome. Functionally distinct classes of molecules identified by bead array assays

\begin{tabular}{|c|c|c|}
\hline & ID/concentration (pg/mL) & Description/function \\
\hline \multirow[t]{2}{*}{ ECM proteins } & Matrix metalloproteinase (MMP-1)/(29,838 \pm 385$)$ & $\begin{array}{l}\text { Involved in collagen degradation, ECM remodelling cell } \\
\text { migration [22] and angiogenesis [23]. }\end{array}$ \\
\hline & Tissue inhibitor of metalloproteinase $($ TIMP-1)/(> 771,464) & Inhibitor of MMPs and regulator of cell migration [22]. \\
\hline \multirow[t]{3}{*}{$\begin{array}{l}\text { Growth factors and } \\
\text { modulatory proteins }\end{array}$} & Hepatocyte growth factor (HGF)/(1817 \pm 38$)$ & $\begin{array}{l}\text { Accelerates re-epithelialisation. Suppresses inflammation. } \\
\text { Promote angiogenesis [24] }\end{array}$ \\
\hline & Vascular endothelial growth factor (VEGF) $(725 \pm 42)$ & Proangiogenic mediator [25]. \\
\hline & Fibroblast growth factor-2 (FGF-2)/(172 \pm 55$)$ & $\begin{array}{l}\text { Promotes proliferation and migration of fibroblasts and } \\
\text { affect collagen deposition [26]. Contributes to the collagen } \\
\text { maturation [27]. }\end{array}$ \\
\hline \multirow[t]{3}{*}{ Adhesion Molecules } & Vascular cell adhesion protein (VCAM-1)/(32,641 \pm 1538$)$ & $\begin{array}{l}\text { Cell adhesion molecule. Involves in inflammation, cell } \\
\text { proliferation and migration [28]. }\end{array}$ \\
\hline & CD166 (ALCAM)/(89,555 \pm 955$)$ & Regulator of T cells and MMP activity [29]. \\
\hline & CD44/(9344 \pm 938$)$ & Regulator of cell migration, survival and differentiation [30]. \\
\hline \multirow[t]{3}{*}{ Inflammatory cytokines } & Monocyte Chemoattractant Protein-1 (MCP-1)/(17 \pm 1$)$ & $\begin{array}{l}\text { Controls the migration and recruitment of monocytes/ } \\
\text { macrophages during inflammation [31]. }\end{array}$ \\
\hline & Interleukins (IL): IL-8 (262 \pm 110$), \mathrm{IL}-2(21 \pm 2), \mathrm{IL}-1 \beta(9 \pm 0)$ & Pro-inflammatory cytokines [32]. \\
\hline & $\mathrm{IL}-6(1150 \pm 414)$ & $\begin{array}{l}\text { A pro-inflammatory cytokine and an anti-inflammatory } \\
\text { cytokine [33] }\end{array}$ \\
\hline
\end{tabular}




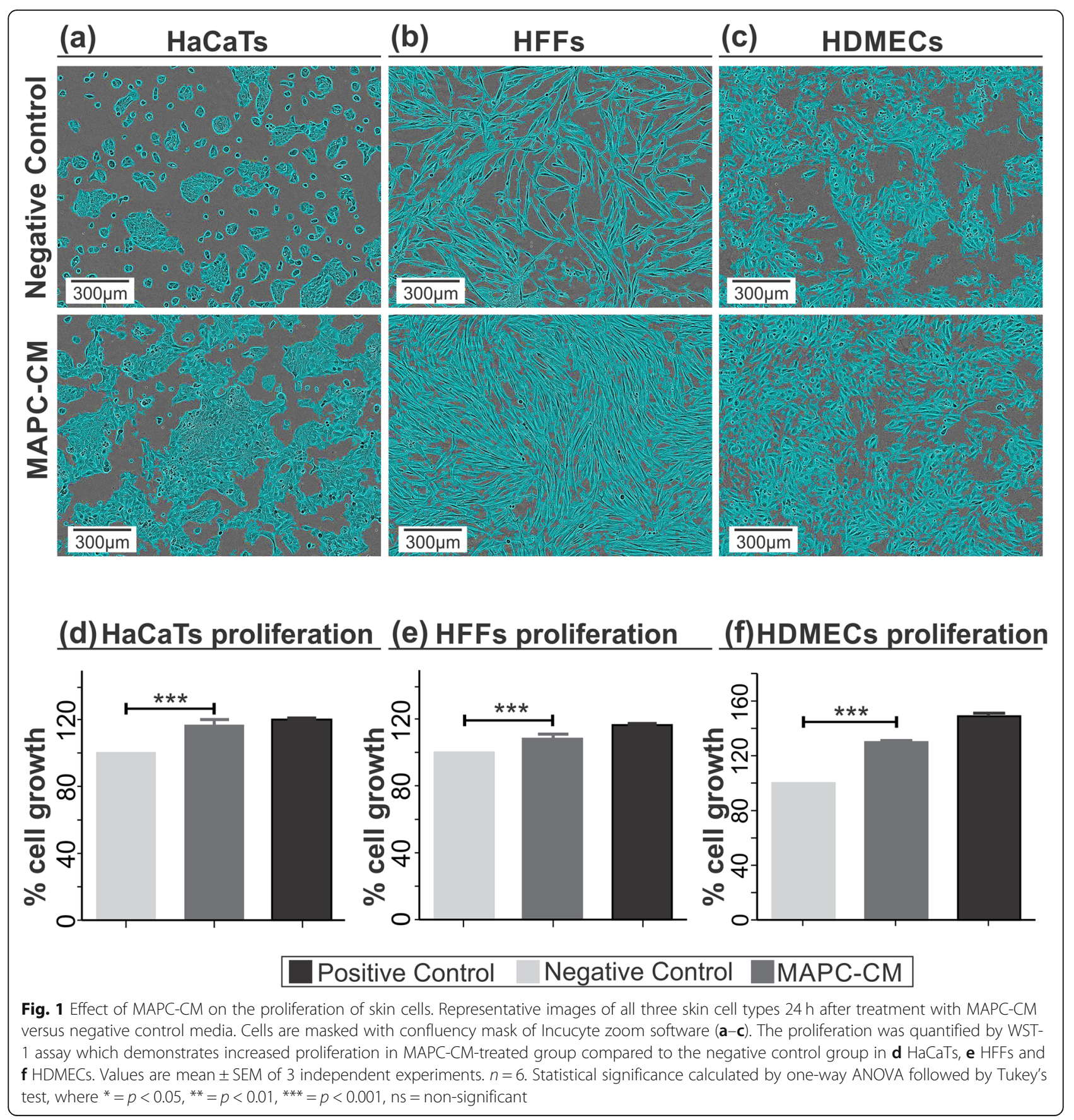

\section{MAPC-CM enhances collagens I and III deposition of fibroblasts}

In order to assess the potential effect of MAPC-CM on collagen deposition, cultured HFFs were incubated with MAPC-CM for $60 \mathrm{~h}$ prior to staining with collagen I or collagen III antibodies. Cells stained immunocytochemically were imaged on a Zeus microscope (Olympus, Tokyo, Japan) and analysed using cellSense software (Fig. 4a). For intensity measurements, the mean grey intensity value was measured across the well. Collagen I and III expressions quantified as mean grey intensity within the well. The intensity for collagen I was increased by 1.2-fold in cells that were treated with MAPC-CM compared to those that were incubated in FBS-free DMEM (negative control) indicating a significant increase in the collagen I deposition with MAPC-CM treatment (Fig. 4b). The deposition of collagen III by fibroblasts was elevated to 1.05-fold following MAPC-CM stimulation compared to the negative control (Fig. 4c). In both cases, deposition of collagens I and III in response to MAPC- 


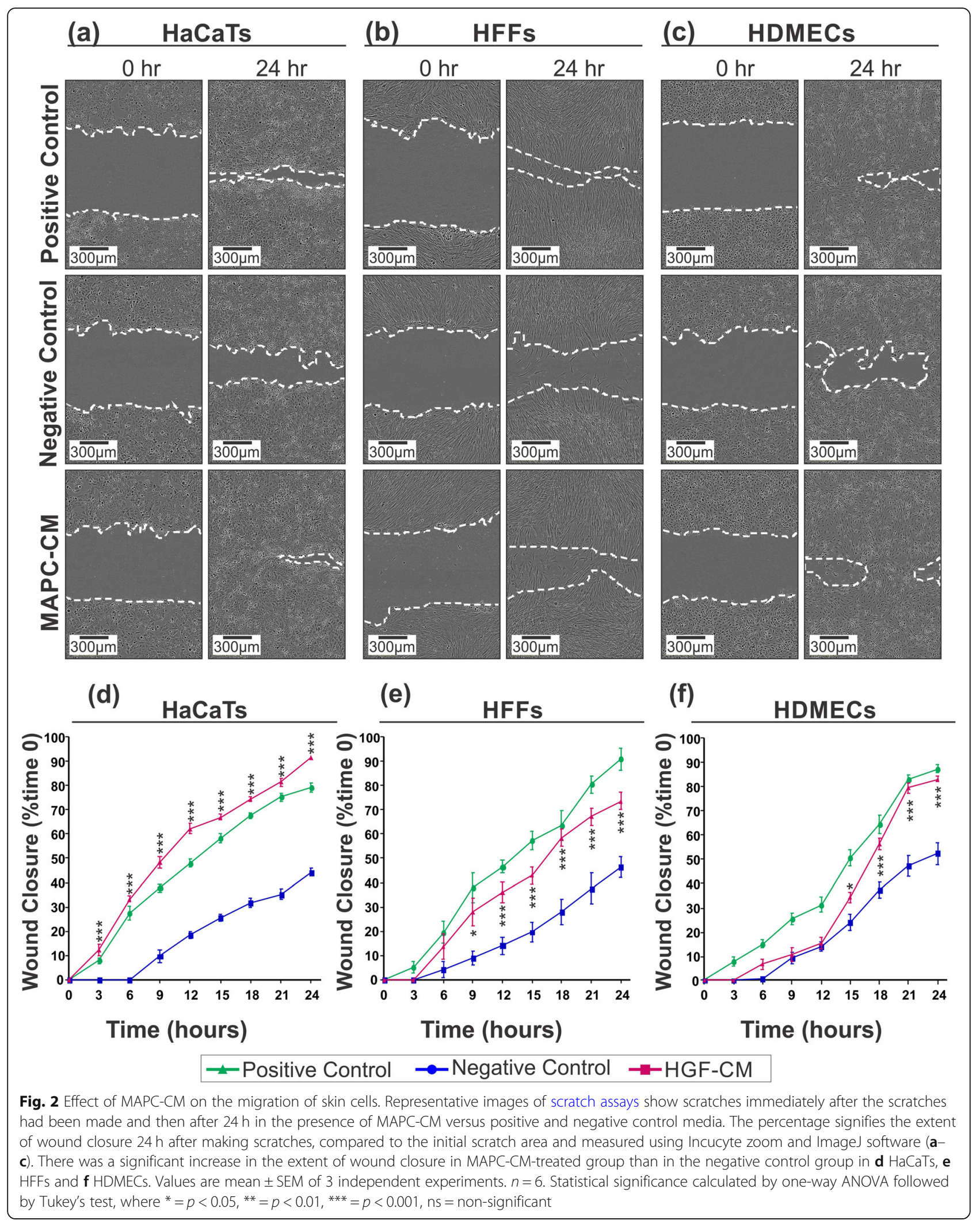




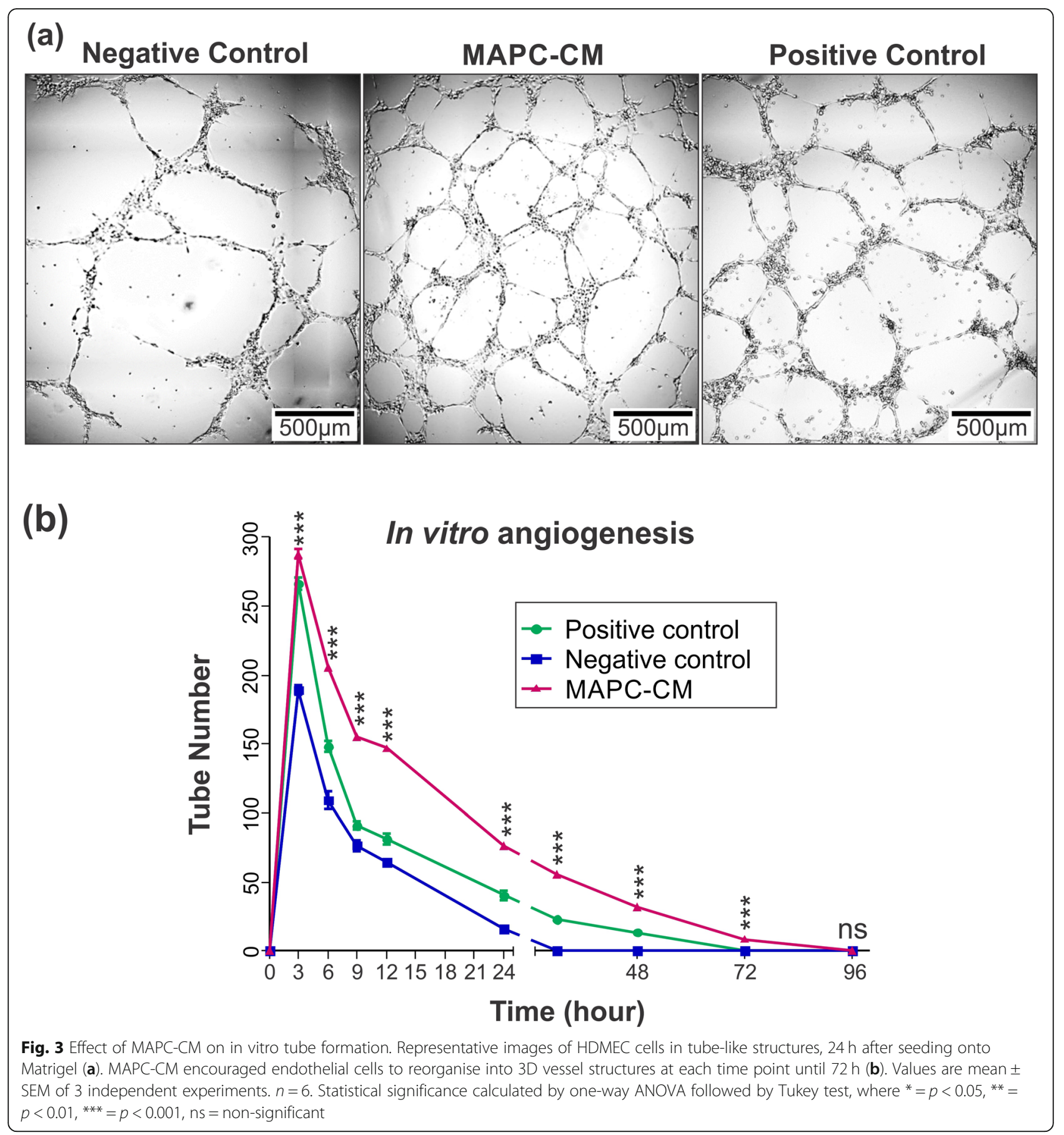

CM treatment were higher than FBS-containing DMEM (positive control) (Fig. 4b, c).

The total number of cells, stained positive with DAPI nuclear stain, were counted to assess the impact of HFF proliferation on the amounts of collagens I and III. The total number of HFFs either in collagen I or collagen III experiment was not significantly different between the cells incubated with MAPC-CM, FBS-free DMEM (negative control) or DMEM with 10\% FBS (positive control). This non-significant difference was probably due to the contact inhibition effect, which indicates that the increase in the collagen deposition of HFFs was not due to a corresponding increase in HFF numbers during culture (Fig. 4d, e).

\section{MAPC-CM treatment improves wound healing in} excisional wounds

The effects of MAPC-CM on cutaneous repair and reepithelialisation was determined using an excisional murine 

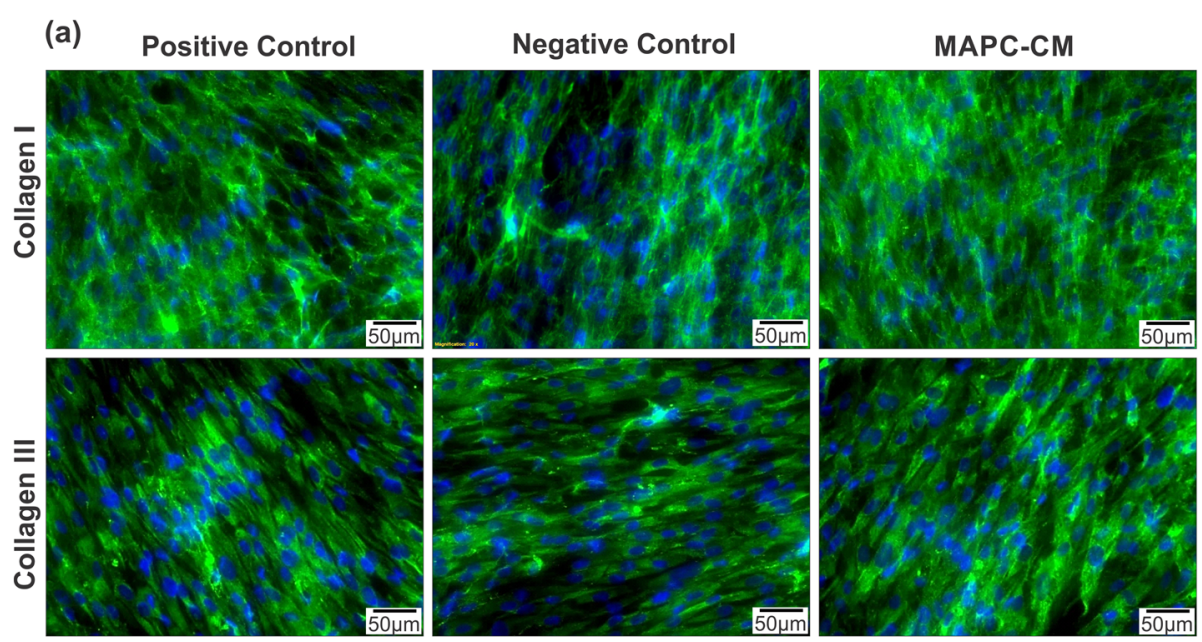

(b)

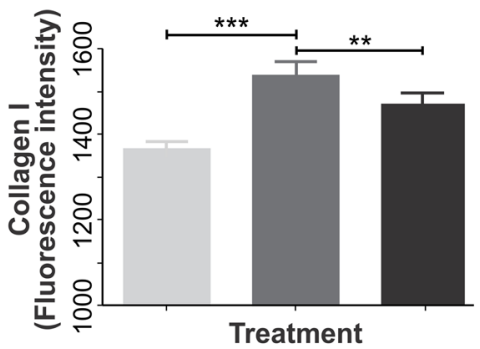

(d)

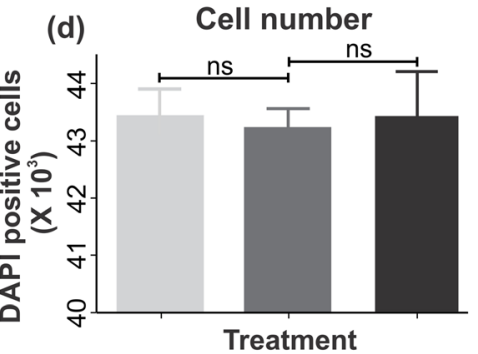

(c) Collagen III

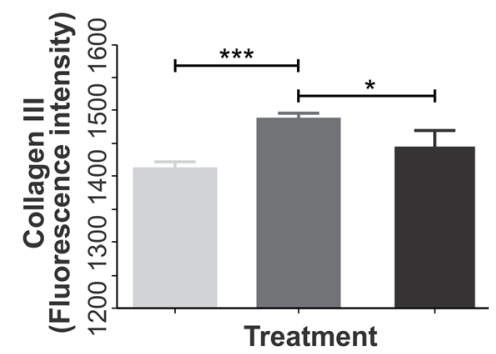

(e)

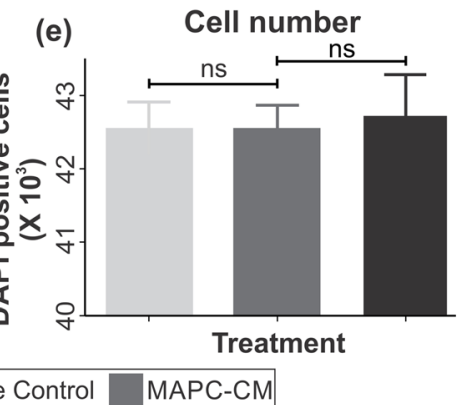

Fig. 4 Effect of MAPC-CM on collagens I and III production of HFFs. Representative images of HFFs treated with MAPC-CM versus positive and negative control media stained for collagen I and collagen III (a). Fluorescence intensities measured using CellSens dimension software (version 1.12), which show that MAPC-CM increases collagens I and III production by HFFs (b, c). HFFs were also stained with DAPI and cell numbers in each well were counted $(\mathbf{d}, \mathbf{e})$. Data are presented as mean \pm SEM. $n=6$. Statistical significance calculated by one-way ANOVA followed by Tukey's test, where ${ }^{*}=p<0.05,{ }^{* *}=p<0.01,{ }^{* * *}=p<0.001$, ns $=$ non-significant

wound healing model. Macroscopic analysis of wounds treated with MAPC-CM showed a significant reduction in average wound area compared to DMEM-treated wounds (control groups) at days 3, 7 and 14 of healing (Fig. 5a, b).

Histological analysis of wound morphology in H\&Estained paraffin-embedded wound tissues (Fig. 5c) also showed decreased microscopic wound area (Fig. 5d) and wound width (Fig. 5e) in MAPC-CM-treated wounds at days 3,7 and 14 of healing. Further analysis of H\&Estained wound tissues at day 3 of healing revealed $15 \%$ reepithelialisation of the wounds in the MAPC-CM-treated group compared with $6 \%$ in the control group. At day 7 of healing, wounds in MAPC-CM-treated mice were $90 \%$ reepithelialised (Fig. 5f). In contrast, wounds from control mice reached only $78 \%$ re-epithelialisation by day 7 . At day 14 of healing, all wounds in both MAPC-CM-treated and control mice were fully re-epithelialised (Fig. 5f).

\section{MAPC-CM treatment decreases inflammatory response in excisional wounds}

To explore the impact of MAPC-CM on inflammation, immunofluorescent staining of neutrophil marker NIMP- 


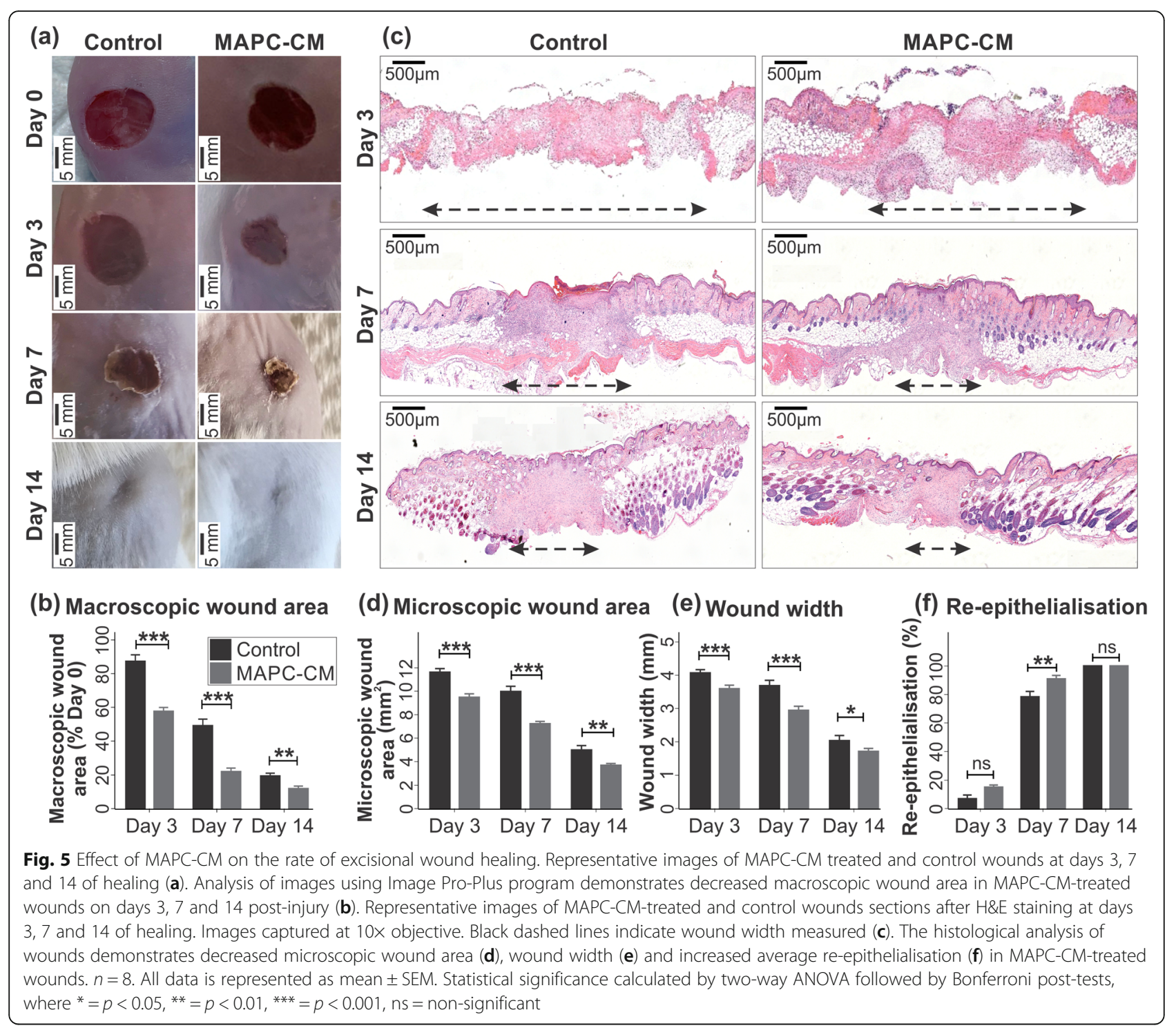

R14 and macrophage marker F4/80 was carried out to quantify neutrophil and macrophage infiltration into the wound bed. Figure 6a shows fluorescence microscopy images of wounds, where the highest number of neutrophils was observed at day 3 of healing. This is expected as infiltration of neutrophils begins at the early stages of the inflammatory phase [34]. Neutrophil numbers decreased at days 7 and 14 of healing. This reduction can be explained by the fact that immune cells undergo apoptosis to resolve inflammation over the course of healing [34]. Quantification of NIMP-R14-positive cells in the wound area indicated less inflammatory cell infiltration to the wound bed in MAPC-CM-treated mice compared to the control group at days 3, 7 and 14 of healing (Fig. $6 \mathrm{~b}$ ). The quantification of macrophage infiltration using macrophage marker $(\mathrm{F} 4 / 80)$ demonstrated a decrease in the presence of F4/80-positive macrophages in MAPC-CM-treated wounds at day 7 (Fig. 6c, d). The percentage of M2 antiinflammatory macrophages expressing $\mathrm{Ym}-1$ indicated that the rate of polarisation of macrophages to an antiinflammatory state was increased by MAPC-CM treatment at 7 days of healing (Fig. 6c, e).

\section{MAPC-CM treatment increases endothelial cell number and angiogenesis in excisional wounds}

In order to investigate the effect of MAPC-CM on angiogenesis, the tissues were immunostained with endothelial cell marker, CD31 (Fig. 7a). The number of CD31-positive endothelial cells and blood vessels was increased from day 3 to day 7 but reduced at day 14. Increased numbers of CD31-positive endothelial cells in MAPC-CM-treated wounds were observed at each time point when compared to the control group (Fig. 7b). Capillary density, as measured by the number of mature 


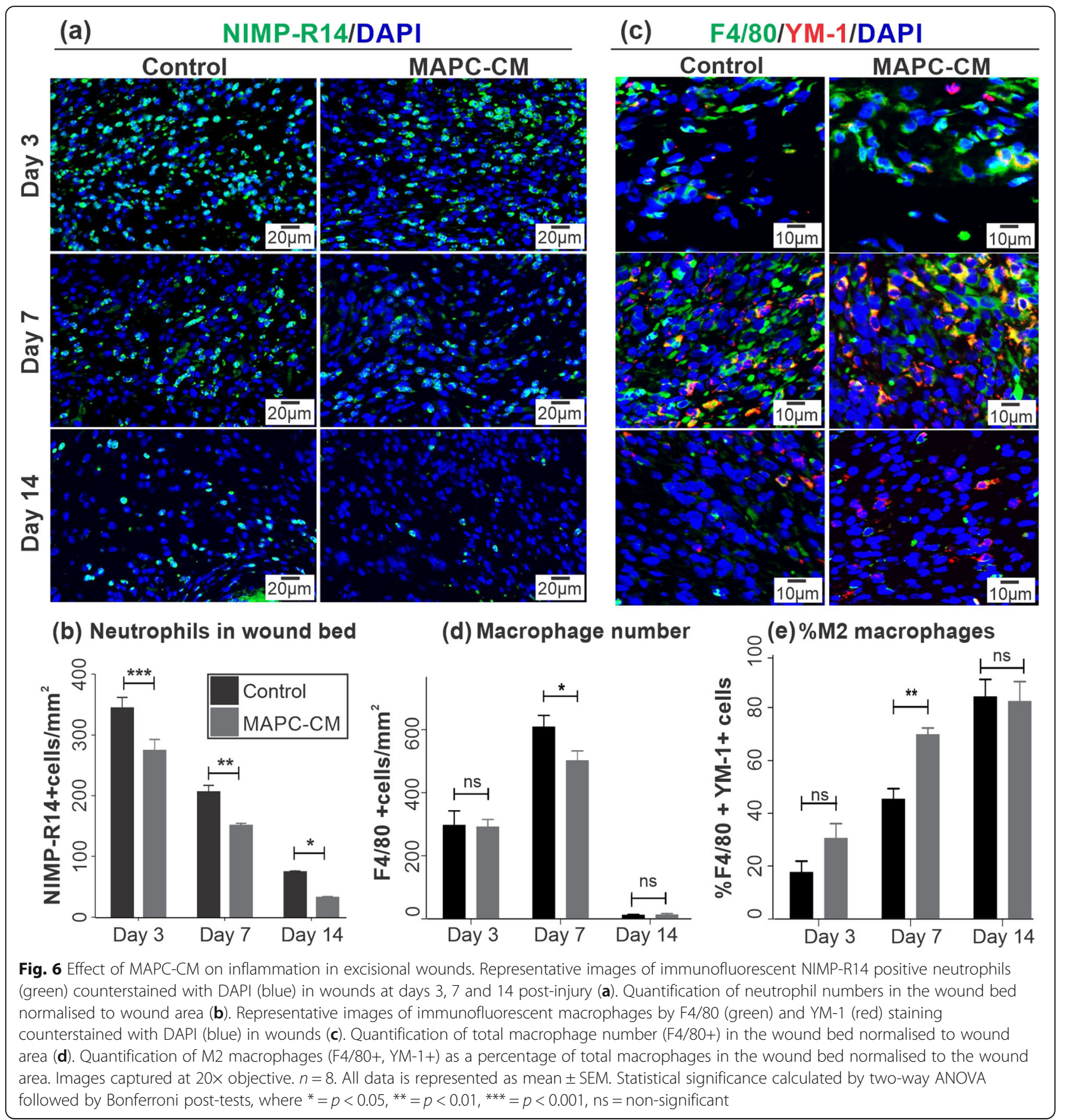

vessels per $\mathrm{mm}^{2}$, was also significantly increased in MAPC-CM-treated wounds at days 7 and 14 of healing (Fig. 7c).

\section{MAPC-CM treatment elevates collagen expression in excisional wounds}

Masson's trichrome staining was undertaken to measure the total amount of collagen in wound tissues (Fig. 8a). The analysis of stained sections revealed that total collagen in MAPC-CM-treated wounds on day 7 and day 14 was elevated significantly compared to control wounds (Fig. 8b).

In order to investigate the effect of MAPC-CM on the expression of different collagen types, the wound tissues were stained with collagen I and collagen III antibodies (Fig. 8c). Results show that both collagens I and III expression was increased at day 7 in MAPC-CM-treated wounds. Collagen I expression was also elevated in MAPC-CM-treated wounds at day 14 of healing while there was no significant difference in collagen III 


\section{(a)}

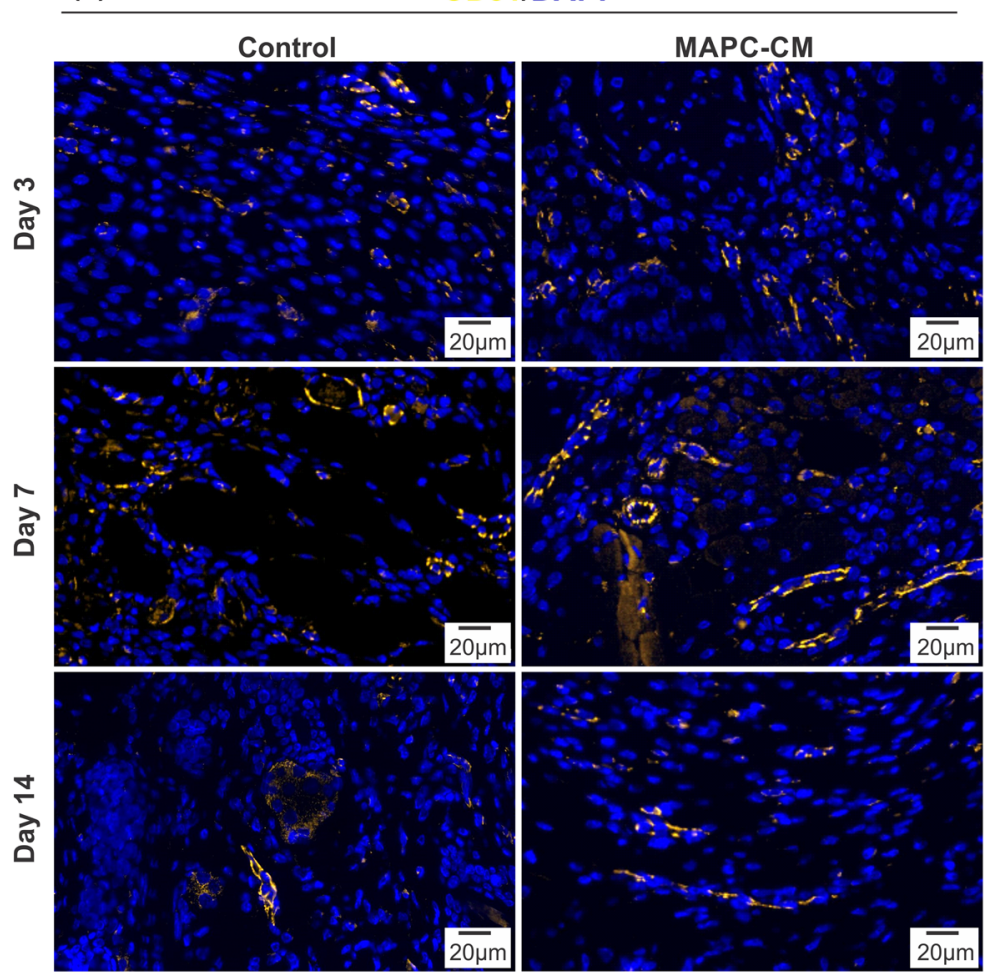

(b) Endothelial cells in wound bed

(c)
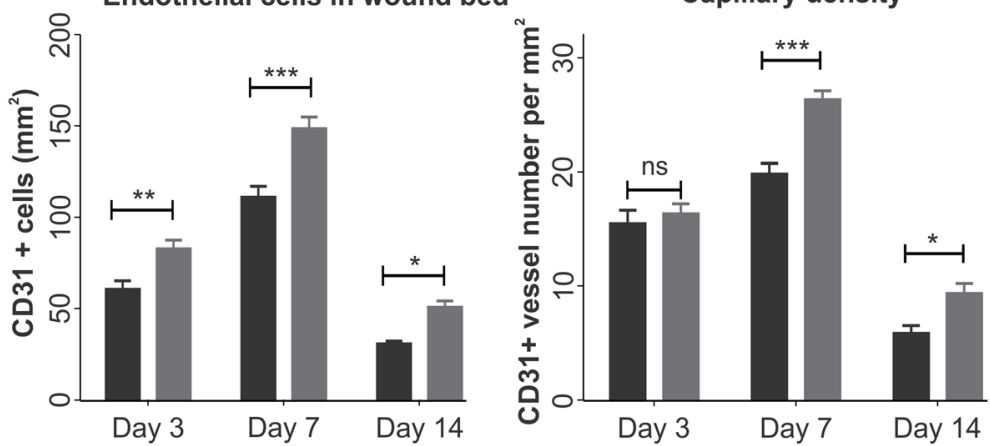

Control MAPC-CM

Fig. 7 Effect of MAPC-CM on angiogenesis in excisional wounds. Representative images of immunofluorescent detection of endothelial cells and blood vessels by CD31 staining (yellow) counterstained with DAPI (blue) at wounds. Images captured at 20x objective (a). Quantification of endothelial cells in the wound bed normalised to the area (b). Quantification of blood vessels in the wound bed normalised to the area (c). $n=8$. All data is represented as mean \pm SEM. Statistical significance calculated by two-way ANOVA followed by Bonferroni post-tests, where $*=p<0.05$, ${ }^{* *}=p<0.01,{ }^{* *}=p<0.001, \mathrm{~ns}=$ non-significant

expression between two groups at day 14 of healing (Fig. 8d, e).

\section{Discussion}

Over the last two decades, stem cells have been extensively used in regenerative medicine due to their positive effects on cardiac, bone and liver regeneration [7]. However, the clinical use of these cells is limited due to the barriers that exist in utilising stem cells including low differentiation capability, cellular senescence and limited replicative lifespan. The translation of stem cell therapies into clinical products has further been limited due to low cell survival and poor engraftment, immunogenicity and tumorigenicity of cells after administration [35] Recent studies have suggested that stem cells secrete biomolecules into their environments that are beneficial for inducing cell differentiation and functional responses important for tissue repair [11]. 


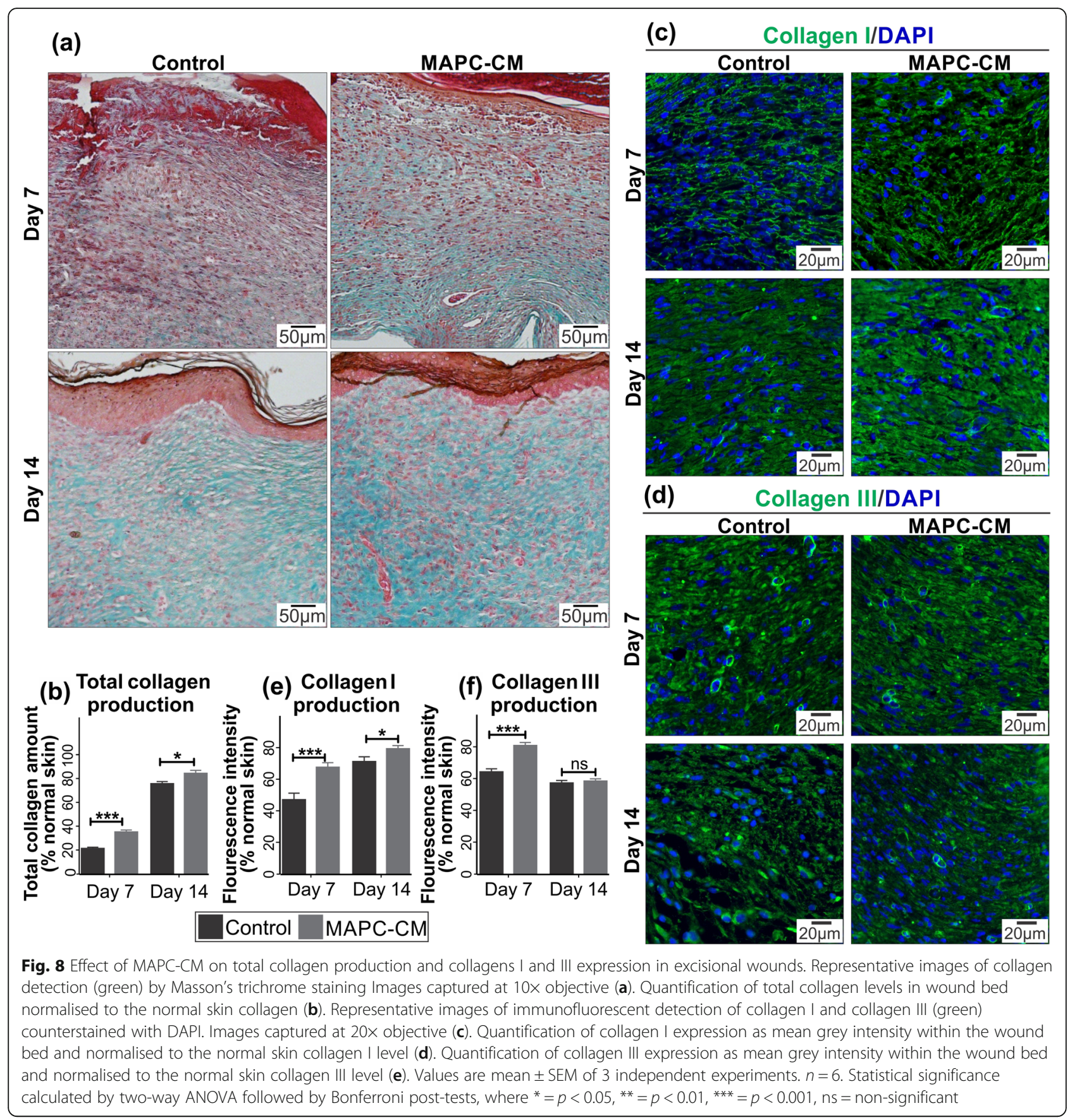

MSCs have been previously shown to have paracrine effects on regulating angiogenesis, promoting tissue remodelling and recruiting other cells as well as having immunomodulatory, anti-inflammatory and anti-fibrosis effects [36-39]. Although MAPC cells and MSCs have some similarities, in that both are bone marrow-derived adherent and non-haematopoietic stem cells [14], their secretome is different as the composition and therapeutic benefit of the secretome can be impacted by isolation methods, culture and storage conditions [40].
In the present study, treatment of excisional wounds with MAPC-secretome in the form of MAPC-CM led to improved wound healing outcomes evidenced by decreased wound area, wound width and inflammatory cell infiltration as well as increases re-epithelialisation. Furthermore, MAPC-CM-treated wounds displayed reduced inflammation, increased angiogenesis and increased amounts of collagens I and III.

MAPC cells possess broader expansion capacities than MSCs and do not show signs of cell senescence, 
karyotypic abnormalities and telomere shortening [41]; these facilitate large scale production of MAPC cells and MAPC-secretome for therapeutic treatment.

Previous studies have reported the effectiveness of live MAPC cell treatment on wound healing in mice [42-44]. Herein, MAPC-CM is shown to be equally as effective as MAPC cell treatment with macroscopic and histological analyses of wound tissues confirming enhanced wound closure time and increased rate of re-epithelialisation. This is consistent with the in vitro studies showing a clear beneficial effect of MAPC-CM on keratinocyte and fibroblast proliferation and migration. Analysis of MAPC-CM suggests that its effect could be partly due to the presence of secreted proteins that have a significant impact on the proliferation and migration of keratinocytes and fibroblasts including FGF-2, MMP-1 and HGF [23].

MAPC cells have previously been reported to have immunomodulatory and anti-inflammatory potential both in in vitro culture and in recipients [45]. In the present study, the analysis of NIMP-R14-stained wound tissues suggested there was reduced inflammation in the MAPC-CM-treated wounds evidenced by a significant reduction in neutrophilic infiltration. In addition, the number of macrophages in wounds were also lower in MAPC-CM-treated wounds. The polarisation of inflammatory M1 macrophages to anti-inflammatory M2 macrophages was also promoted in MAPC-CM-treated wounds. The anti-inflammatory effect may be explained by the secretion of cytokines and growth factors by MAPC cells into the conditioned media that contribute to inflammatory cell infiltration and resolution. Analysis of the bead array assays confirmed that MAPC-CM contains high concentrations of inflammatory cytokines mainly IL-6 (both pro and anti-inflammatory cytokine). Our findings are also consistent with other studies that have confirmed the secretion of various pro/anti-inflammatory cytokines including IL-6, IL-10, IL1 $\alpha$, IL8 and TNF $\alpha$ by MAPC cells [19].

In the proliferation phase of wound healing, fibroblasts migrate to the wound site and secrete components of ECM mainly collagens I and III within the wound bed. During the remodelling phase, the relative proportions of collagens I and III changes (type I collagen content increases while collagen type III decreases), and total collagen content increases. These functions are all required for wound contraction [2, 46]. MAPC-CM was found to contain secreted collagens, ECM proteins and other growth factors which mediate ECM production and remodelling [19]. In this study, we also have found that the production of collagens I and III by dermal fibroblasts was augmented when they were treated with MAPC-CM in vitro. Additionally, measuring collagen expression in mice treated with MAPC-CM showed an increase in the production of both collagen I and III at day 7 and collagen I production at 14 post-injury while there was no difference in the amount of collagen III at day 14. This result confirmed the improvement of collagen remodelling in MAPC-CM-treated wounds. This improvement could be partly due to the presence of FGF-2 in MAPC-CM, which has been shown to induce collagen production [47].

Failure of neovascularization and angiogenesis is another important factor which contributes to impaired wound healing [48]. Our results revealed an increase in proliferation and migration in endothelial cells in the presence of MAPC-CM. Endothelial cells treated with MAPC-CM also formed more vessel-like tubes than untreated ones. Furthermore, formed tubes persisted in culture for longer when treated with MAPC-CM. Accordingly, the number of endothelial cells and blood vessels was also increased in MAPC-CM-treated wounds which shows the significant effects of MAPC-CM on angiogenesis and wound healing. The number of endothelial cells and blood vessels were increased in MAPC-CM-treated wounds which shows the significant effects of MAPC-CM on angiogenesis and wound healing. We also showed that MAPC$\mathrm{CM}$ contains VEGF which is a proangiogenic factor with an ability to stimulate proliferation, migration and vessel formation of endothelial cells $[19,49]$.

Overall, histological and immunohistochemistry observations, taken together with the morphometric parameters, demonstrated that wounds treated with MAPC-CM show improved healing responses. This improvement was mediated through a combination of reduced inflammation and enhanced re-epithelialisation, angiogenesis and collagen production. This study suggests the use of MAPC-CM as a promising alternative to stem cell-based therapies for the treatment of wounds.

\section{Conclusion}

Intradermal administration of MAPC cell secretome appears to be safe and enhances cutaneous wound healing by promoting skin cell proliferation and migration, balancing inflammation and improving the formation of extracellular matrix and angiogenesis. These results provide preclinical evidence that supports the translation of stem cell-free therapy for the treatment of wounds.

\section{Supplementary information}

Supplementary information accompanies this paper at https://doi.org/10. 1186/s13287-020-01819-z.

\section{Additional file 1.}

\section{Abbreviations}

ALCAM: Activated leukocyte cell adhesion molecule; CD31: Cluster of differentiation 31; DAPI: 4',6-Diamidino-2-phenylindole; DMEM: Dulbecco's modified Eagle's medium; ECM: Extracellular matrix; FBS: Foetal bovine serum; FGF-2: Fibroblast growth factor-2; H\&E: Haematoxylin and eosin; 
HDMECs: Human dermal microvascular endothelial cells; HFFs: Human foreskin fibroblasts; HGF: Hepatocyte growth factor; IL: Interleukin; MAPC cells: Multipotent adult progenitor cells; MAPC-CM: Multipotent adult progenitor cells-conditioned medium; MCP-1: Monocyte Chemoattractant Protein-1; MMP-1: Matrix metalloproteinase; MSCs: Mesenchymal stem cells; NGS: Normal goat serum; PBS: Phosphate-buffered saline; TIMP-1: Tissue inhibitor of metalloproteinase; TNF-a: Tumour necrosis factor alpha; VCAM: Vascular cell adhesion protein; VEGF: Vascular endothelial growth facto

\section{Acknowledgements}

We thank our colleagues from Future Industries Institutes, University of South Australia. The authors also acknowledge the facilities and scientific and technical assistance of Microscopy Australia at the University of South Australia, a facility that is funded by the University of South Australia and the State and Federal Governments.

\section{Authors' contributions}

P.A designed and conducted the study, analysed the data and wrote the manuscript. S.J.M designed and conducted the study and analysed the data. L.E.S and X.L.S analysed the data and reviewed the manuscript. A.E.T and B. V reviewed the manuscript. A.J.C designed the study, analysed the data and wrote and reviewed the manuscript. The authors read and approved the final manuscript.

\section{Funding}

This research was supported by the Cell Therapy Manufacturing CRC (CTM CRC). Additionally, P. A received a University President's Postgraduate Scholarship and A.J.C is supported by a NHMRC Senior Research Fellowship GNT\#1102617.

\section{Availability of data and materials}

The data that support the findings of this study are available from the corresponding author upon reasonable request.

\section{Ethics approval and consent to participate}

This research was conducted according to the University of South Australia Animal Ethics Committee following the Australian Code of Practice for the Care and the Use of Animals for Scientific Purposes (AEC: U39-18; 2 January 2019)

\section{Consent for publication}

Not applicable.

\section{Competing interests}

The MAPC cells were provided by Athersys who hold IP protecting the use of the cells and were also a partner in the CTM CRC.

\section{Author details}

${ }^{1}$ Future Industries Institute, University of South Australia, Adelaide, SA 5000, Australia. ${ }^{2}$ Cell Therapy Manufacturing Cooperative Research Centre, Adelaide, SA 5000, Australia. ${ }^{3}$ Athersys, Inc., Cleveland, OH, USA. ${ }^{4}$ ReGenesys BVBA, Bio-Incubator Leuven, Gaston Geenslaan 1, 3001 Heverlee, Belgium.

\section{Received: 10 May 2020 Revised: 15 June 2020}

\section{Accepted: 8 July 2020 Published online: 17 July 2020}

\section{References}

1. Shaw TJ, Martin P. Wound repair at a glance. J Cell Sci. 2009;122(18):3209-13.

2. Darby IA, Laverdet $B$, Bonté $F$, Desmoulière A. Fibroblasts and myofibroblasts in wound healing. Clin Cosmet Investig Dermatol. 2014;7: 301-11.

3. Gurtner GC, Werner S, Barrandon Y, Longaker MT. Wound repair and regeneration. Nature. 2008;453(7193):314-21.

4. Coentro JQ, Pugliese E, Hanley G, Raghunath M, Zeugolis DI. Current and upcoming therapies to modulate skin scarring and fibrosis. Adv Drug Deliv Rev. 2019;146:37-59.

5. Kosaric N, Kiwanuka H, Gurtner GC. Stem cell therapies for wound healing Expert Opin Biol Ther. 2019;19(6):575-85.

6. Ahangar P, Woodward. M, Cowin AJ. Advanced wound therapies Wound Practice \& Research: J Australian Wound Management Assoc 2018;26(2):58-68.
7. Zakrzewski W, Dobrzyński M, Szymonowicz M, Rybak Z. Stem cells: past, present, and future. Stem Cell Res Ther. 2019;10(1):68.

8. Simpson D, Liu H, Fan T-HM, Nerem R, Dudley SC Jr. A tissue engineering approach to progenitor cell delivery results in significant cell engraftment and improved myocardial remodeling. Stem Cells (Dayton, Ohio). 2007;25(9): 2350-7.

9. Picinich SC, Mishra PJ, Mishra PJ, Glod J, Banerjee D. The therapeutic potential of mesenchymal stem cells. Cell- \& tissue-based therapy. Expert Opin Biol Ther. 2007;7(7):965-73.

10. Park S-R, Kim J-W, Jun H-S, Roh JY, Lee H-Y, Hong I-S. Stem cell secretome and its effect on cellular mechanisms relevant to wound healing. Mol Ther. 2018;26(2):606-17.

11. Baraniak PR, McDevitt TC. Stem cell paracrine actions and tissue regeneration. Regen Med. 2010;5(1):121-43.

12. Jiang $Y$, Jahagirdar BN, Reinhardt RL, Schwartz RE, Keene CD, Ortiz-Gonzalez $X R$, et al. Pluripotency of mesenchymal stem cells derived from adult marrow. Nature. 2002:418(6893):41-9.

13. Jiang $Y$, Vaessen $B$, Lenvik T, Blackstad M, Reyes M, Verfaillie CM. Multipotent progenitor cells can be isolated from postnatal murine bone marrow, muscle, and brain. Exp Hematol. 2002;30(8):896-904.

14. Sohni A, Verfaillie CM. Multipotent adult progenitor cells. Best Pract Res Clin Haematol. 2011;24(1):3-11.

15. Hof Wvt, Mal N, Raber A, Zhang M, Ting A, S. M, et al. Multipotent adult progenitor cells. In: Penn MS, editor. Stem cells and myocardial regeneration. Totowa, NJ: Humana Press; 2007. 45-56.

16. Crabbé MA, Gijbels K, Visser A, Craeye D, Walbers S, Pinxteren J, et al. Using miRNA-mRNA interaction analysis to link biologically relevant miRNAs to stem cell identity testing for next-generation culturing development. Stem Cells Transl Med. 2016;5(6):709-22.

17. Roobrouck VD, Clavel C, Jacobs SA, Ulloa-Montoya F, Crippa S, Sohni A, et al. Differentiation potential of human postnatal mesenchymal stem cells, mesoangioblasts, and multipotent adult progenitor cells reflected in their transcriptome and partially influenced by the culture conditions. Stem Cells (Dayton, Ohio). 2011;29(5):871-82.

18. Khan RS, Newsome PN. A comparison of phenotypic and functional properties of mesenchymal stromal cells and multipotent adult progenitor cells. Front Immunol. 2019;10:1952. https://www.frontiersin.org/article/10.33 89/fimmu.2019.01952.

19. Burrows GG, van't Hof W, Newell LF, Reddy A, Wilmarth PA, David LL, et al. Dissection of the human multipotent adult progenitor cell secretome by proteomic analysis. Stem Cells Transl Med. 2013;2(10):745-57.

20. Adams DH, Shou Q, Wohlmuth $H$, Cowin AJ. Native Australian plant extracts differentially induce collagen I and collagen III in vitro and could be important targets for the development of new wound healing therapies. Fitoterapia. 2016:109:45-51.

21. Cowin AJ, Adams DH, Strudwick XL, Chan H, Hooper JA, Sander GR, et al. Flightless I deficiency enhances wound repair by increasing cell migration and proliferation. J Pathol. 2007;211(5):572-81.

22. Newby AC. Matrix metalloproteinases regulate migration, proliferation, and death of vascular smooth muscle cells by degrading matrix and non-matrix substrates. Cardiovasc Res. 2006:69(3):614-24.

23. Grzela T, Krejner-Bienias A, Litwiniuk M. Matrix metalloproteinases in the wound microenvironment: therapeutic perspectives. Chronic Wound Care Management and Research. 2016;2016:29.

24. Cowin AJ, Kallincos N, Hatzirodos N, Robertson JG, Pickering KJ, Couper J, et al. Hepatocyte growth factor and macrophage-stimulating protein are upregulated during excisional wound repair in rats. Cell Tissue Res. 2001; 306(2):239-50.

25. Johnson KE, Wilgus TA. Vascular endothelial growth factor and angiogenesis in the regulation of cutaneous wound repair. Advances in Wound Care. 2014;3(10):647-61.

26. Song YH, Zhu YT, Ding J, Zhou FY, Xue JX, Jung JH, et al. Distribution of fibroblast growth factors and their roles in skin fibroblast cell migration. Mol Med Rep. 2016:14:3336-42.

27. Dantas Filho AM, Aguiar JLdA, Rocha LRdM, Azevedo ÍM, Ramalho E, Medeiros AC Effects of the basic fibroblast growth factor and its anti-factor in the healing and collagen maturation of infected skin wound Acta Cirurgica Brasileira 2007:22:64-71.

28. Koivisto L, Heino J, Häkkinen L, Larjava H. Integrins in wound healing. Advances Wound Care. 2014:3(12):762-83. 
29. Czopik AK, Bynoe MS, Palm N, Raine CS, Medzhitov R. Semaphorin 7A is a negative regulator of T cell responses. Immunity. 2006;24(5):591-600.

30. Ponta $H$, Sherman L, Herrlich PA. CD44: from adhesion molecules to signalling regulators. Nat Rev Mol Cell Biol. 2003;4(1):33-45.

31. Siddiqui JA, Partridge NC. CCL2/monocyte chemoattractant protein 1 and parathyroid hormone action on bone. Front Endocrinol. 2017:8:49.

32. Su D-L, Lu Z-M, Shen M-N, Li X, Sun L-Y. Roles of pro- and antiinflammatory cytokines in the pathogenesis of SLE. J Biomed Biotechnol. 2012;2012:347141.

33. Xing Z, Gauldie J, Cox G, Baumann H, Jordana M, Lei XF, et al. IL-6 is an antiinflammatory cytokine required for controlling local or systemic acute inflammatory responses. J Clin Invest. 1998;101(2):311-20.

34. Wu Y-S, Chen S-N. Apoptotic cell: linkage of inflammation and wound healing. Front Pharmacol. 2014;5:1.

35. Kim HJ, Park J-S. Usage of human mesenchymal stem cells in cell-based therapy: advantages and disadvantages. Development Reproduction. 2017; 21(1):1-10.

36. Ferreira JR, Teixeira GQ, Santos SG, Barbosa MA, Almeida-Porada G, Gonçalves RM. Mesenchymal stromal cell secretome: influencing therapeutic potential by cellular pre-conditioning. Front Immunol. 2018;9: 2837. https://www.frontiersin.org/article/10.3389/fimmu.2018.02837.

37. Guillén MI, Platas J, Pérez del Caz MD, Mirabet V, Alcaraz MJ. Paracrine antiinflammatory effects of adipose tissue-derived mesenchymal stem cells in human monocytes. Front Physiol. 2018;9:661. https://www.frontiersin.org/ article/10.3389/fphys.2018.00661.

38. Pankajakshan $D$, Agrawal DK. Mesenchymal stem cell paracrine factors in vascular repair and regeneration. J Biomed Technol Res. 2014;1(1):https:// doi.org/10.19104/jbtr.2014.107.

39. Usunier B, Benderitter M, Tamarat R, Chapel A. Management of fibrosis: the mesenchymal stromal cells breakthrough. Stem Cells Int. 2014;2014:340257-

40. Pawitan JA. Prospect of stem cell conditioned medium in regenerative medicine. Biomed Res Int. 2014;2014:965849.

41. Maziarz RT, Devos T, Bachier CR, Goldstein SC, Leis JF, Devine SM, et al. Single and multiple dose MultiStem (multipotent adult progenitor cell) therapy prophylaxis of acute graft-versus-host disease in myeloablative allogeneic hematopoietic cell transplantation: a phase 1 trial. Biol Blood Marrow Transplantation. 2015:21(4):720-8.

42. Kirby GTS, Mills SJ, Cowin AJ, Smith LE. Stem cells for cutaneous wound healing. Biomed Res Int. 2015;2015:11.

43. Kirby GTS, Mills SJ, Vandenpoel L, Pinxteren J, Ting A, Short RD, et al. Development of advanced dressings for the delivery of progenitor cells. ACS Appl Mater Interfaces. 2017;9(4):3445-54.

44. Beerens M, Aranguren XL, Hendrickx B, Dheedene W, Dresselaers T, Himmelreich U, et al. Multipotent adult progenitor cells support lymphatic regeneration at multiple anatomical levels during wound healing and lymphedema. Scientific Reports. 2018:8(1):3852-.

45. Carty F, Corbett JM, Cunha JPMCM, Reading JL, Tree TIM, Ting AE, Stubblefield SR, English K. Multipotent adult progenitor cells suppress T cell activation in in vivo models of homeostatic proliferation in a prostaglandin E2-dependent manner. Front Immunol. 2018;9:645. https://www.frontiersin. org/article/10.3389/fimmu.2018.00645.

46. Bainbridge. Wound healing and the role of fibroblasts. J Wound Care 2013; 22(8):407-412.

47. Rangarajan V, Dreher F. Topical growth factors for skin rejuvenation. In: Farage MA, Miller KW, Maibach HI, editors. Textbook of aging skin. Berlin, Heidelberg: Springer Berlin Heidelberg; 2010. 1079-87.

48. Bauer SM, Bauer RJ, Velazquez OC. Angiogenesis, vasculogenesis, and induction of healing in chronic wounds. Vasc Endovasc Surg. 2005;39(4): 293-306.

49. Cunha JPMCM, Leuckx G, Sterkendries P, Korf H, Bomfim-Ferreira G, Overbergh $\mathrm{L}$, et al. Human multipotent adult progenitor cells enhance islet function and revascularisation when co-transplanted as a composite pellet in a mouse model of diabetes. Diabetologia. 2017;60(1):134-42.

\section{Publisher's Note}

Springer Nature remains neutral with regard to jurisdictional claims in published maps and institutional affiliations.

\section{Ready to submit your research? Choose BMC and benefit from:}

- fast, convenient online submission

- thorough peer review by experienced researchers in your field

- rapid publication on acceptance

- support for research data, including large and complex data types

- gold Open Access which fosters wider collaboration and increased citations

- maximum visibility for your research: over $100 \mathrm{M}$ website views per year

At BMC, research is always in progress.

Learn more biomedcentral.com/submissions 